\title{
AFLP and phylogenetic analyses of North American and European populations of Phytophthora ramorum
}

\author{
Kelly L. IVORS ${ }^{1 *}$, Katherine J. HAYDEN ${ }^{1}$, Peter J. M. BONANTS ${ }^{2}$, David M. RIZZO ${ }^{3}$ \\ and Matteo GARBELOTTO ${ }^{1}$ \\ ${ }^{1}$ Department of Environmental Science, Policy, and Management - Ecosystem Sciences Division, University of California, \\ Berkeley, CA 94720, USA. \\ ${ }^{2}$ Plant Research International, P.O. Box 16,6700 AA Wageningen, The Netherlands. \\ ${ }^{3}$ Department of Plant Pathology, One Shields Ave., University of California, Davis, CA 95616, USA. \\ E-mail:kivors@nature.berkeley.edu
}

Received 21 September 2003; accepted 19 January 2004.

\begin{abstract}
The genetic structure within and between USA and European populations of the emerging phytopathogen Phytophthora ramorum was examined. Four primer combinations were used for amplified fragment length polymorphism (AFLP) fingerprinting of 67 USA isolates from California and Oregon, and 18 European isolates from Belgium, Germany, The Netherlands, Spain and the UK. In addition, three DNA regions (ITS, cox II, and nad 5) of additional Phytophthora species were amplified by polymerase chain reaction, sequenced, and analysed to provide better phylogenetic understanding of P. ramorum within the genus Phytophthora. AFLP banding patterns indicate that the 85 isolates form two distinct lineages within a monophyletic group, distinct from the closely related outgroup species $P$. lateralis. With the exception of two isolates from an Oregon nursery, European and USA isolates clustered separately within individual clades. The AFLP profiles also indicate that a single clonal lineage dominates the North American population, while the European population consists of an array of mainly unique, closely related AFLP types. Sequences from the three DNA regions were identical among all $P$. ramorum isolates, and phylogenetic analysis indicates that $P$. ramorum is closely related to $P$. lateralis and $P$. hibernalis.
\end{abstract}

\section{INTRODUCTION}

Phytophthora ramorum is considered an emerging pathogen that has received worldwide attention as the causal agent of sudden oak death (SOD; Rizzo \& Garbelotto 2003). In California and Oregon, $P$. ramorum causes a deadly canker disease of tanoak (Lithocarpus densiflora), coast live oak (Quercus agrifolia), California black oak (Q. kelloggii) and Shreve's oak ( $Q$. parvula var. shrevei), and non-lethal foliar and twig infections of numerous native hardwood and coniferous forest trees, understory shrubs and herbaceous plants (Davidson et al. 2003). Symptoms of SOD were first observed during 1994-95 in the San Francisco bay area in California; subsequently $P$. ramorum has reached epidemic proportions in oak forests along a $650 \mathrm{~km}$ stretch of the Pacific coastline from central California to southern Oregon. Recently the pathogen has been found in nurseries in California, Oregon,

\footnotetext{
* Corresponding author.
}

Washington and British Columbia that are located outside the natural range of $P$. ramorum (Davidson et al. 2003). The pathogen was first isolated in 1993 in Germany and The Netherlands from rhododendrons in nurseries and formally described in 2001 (Werres et al. 2001). Since then, P. ramorum has been detected in at least nine European countries, where it is reported to cause twig blight of Rhododendron, Viburnum, Camellia, Kalmia, Pieris, Vaccinium and other important nursery plant species (http://www.eppo.org; Davidson et al. 2003). Recently the pathogen was also isolated from multiple tree species in the vicinity of infected rhododendrons in the UK and The Netherlands (http:// www.defra.gov.uk). A comparison of morphology and ITS DNA sequences of isolates from both geographic locations confirmed that western USA and European isolates were the same species (Rizzo et al. 2002).

The global genetic structure and geographic origin of P. ramorum remain unknown. There are no reports of this species in either the USA or Europe before the mid 1990s. Due to its limited geographic range in relation to 
Table 1. Isolates of Phytophthora species used in this study.

\begin{tabular}{|c|c|c|c|c|}
\hline Isolate number ${ }^{\mathrm{a}}$ & Host & Origin & Experiments & GenBank \\
\hline \multicolumn{5}{|l|}{ P. ramorum (USA) } \\
\hline $\mathrm{Pr}-01^{\mathrm{DR}}, \mathrm{CBS} 110534$ & Quercus agrifolia & Marin Co., CA & AFLP, ITS & AF521564 \\
\hline $\operatorname{Pr}-02^{\mathrm{DR}}$ & Lithocarpus densiflora & Marin Co., CA & AFLP & \\
\hline $\operatorname{Pr}-03^{\mathrm{DR}}, \mathrm{CBS} 110535$ & Lithocarpus densiflora & Marin Co., CA & AFLP & \\
\hline $\operatorname{Pr}-04^{\mathrm{DR}}, \mathrm{CBS} 110536$ & Q. kelloggii & Marin Co., CA & AFLP & \\
\hline Pr-05 DR, ATCC MYA-2434 & L. densiflora & Marin Co., CA & AFLP & \\
\hline Pr-06 ${ }^{\text {DR }}$, ATCC MYA-2435 & Q. agrifolia & Marin Co., CA & AFLP, ITS & AY423276 \\
\hline $\operatorname{Pr}-08^{\mathrm{DR}}$ & Q. agrifolia & Napa Co., CA & AFLP & \\
\hline $\operatorname{Pr}-10^{\mathrm{DR}}$ & L. densiflora & Monterey Co., CA & AFLP & \\
\hline $\operatorname{Pr}-11^{\mathrm{DR}}$ & Q. agrifolia & Monterey Co., CA & AFLP & \\
\hline $\operatorname{Pr}-13^{\mathrm{DR}}$ & Q. agrifolia & Santa Cruz Co., CA & AFLP, ITS & AY423277 \\
\hline $\operatorname{Pr}-16^{\mathrm{DR}}$ & Q. agrifolia $^{\mathrm{N}}$ & Santa Cruz Co., CA & AFLP & \\
\hline $\operatorname{Pr}-19^{\mathrm{DR}}$ & Q. agrifolia & Napa Co., CA & AFLP & \\
\hline $\operatorname{Pr}-20^{\mathrm{DR}}$ & Q. agrifolia & Sonoma, CA & AFLP & \\
\hline $\operatorname{Pr}-22^{\mathrm{DR}}$ & Q. agrifolia & Sonoma Co., CA & AFLP & \\
\hline $\operatorname{Pr}-24^{\mathrm{DR}}$ & Q. agrifolia & Sonoma Co., CA & AFLP & \\
\hline $\operatorname{Pr}-27^{\mathrm{DR}}$ & Q. agrifolia & Marin Co., CA & AFLP & \\
\hline $\operatorname{Pr}-28^{\mathrm{DR}}$ & L. densiflora & Sonoma Co., CA & AFLP & \\
\hline $\operatorname{Pr}-35^{\mathrm{DR}}$ & Q. agrifolia & Sonoma Co., CA & AFLP & \\
\hline Pr-36 $6^{\mathrm{DR}}, \mathrm{CBS} 110953$ & Q. agrifolia & Sonoma Co., CA & AFLP, ITS & AY423278 \\
\hline $\operatorname{Pr}-47^{\mathrm{DR}}$ & Q. agrifolia & Sonoma Co., CA & AFLP & \\
\hline $\operatorname{Pr}-50^{\mathrm{DR}}$ & Q. agrifolia & Sonoma Co., CA & AFLP & \\
\hline Pr-52 & Rhododendron sp. ${ }^{\mathrm{N}}$ & Santa Cruz Co., CA & AFLP, ITS & AF521567 \\
\hline $\operatorname{Pr}-57^{\mathrm{DR}}$ & L. densiflora & Santa Clara Co., CA & AFLP & \\
\hline $\operatorname{Pr}-58^{\mathrm{DR}}$ & Vaccinium ovatum & Marin Co., CA & AFLP & \\
\hline Pr-65 & $Q \cdot$ parvula $^{\mathrm{N}}$ & Santa Cruz Co., CA & AFLP & \\
\hline $\operatorname{Pr}-70^{\mathrm{DR}}, \mathrm{CBS} 110539$ & V. ovatum & Marin Co., CA & AFLP & \\
\hline Pr-71 ${ }^{\mathrm{DR}}, \mathrm{CBS} 110540$ & Q. agrifolia & Sonoma Co., CA & AFLP & \\
\hline $\operatorname{Pr}-72^{\mathrm{DR}}, \mathrm{CBS} 110954$ & Rhododendron sp. ${ }^{\mathrm{N}}$ & Santa Cruz Co., CA & AFLP, ITS & AY423279 \\
\hline $\operatorname{Pr}-73^{\mathrm{DR}}$ & Rhododendron sp. ${ }^{\mathrm{N}}$ & Alameda Co., CA & AFLP & \\
\hline $\operatorname{Pr}-75^{\mathrm{DR}}$ & Q. agrifolia & Monterey Co., CA & AFLP & \\
\hline $\operatorname{Pr}-80^{\mathrm{DR}}$ & V. ovatum & Marin Co., CA & AFLP & \\
\hline $\operatorname{Pr}-82^{\mathrm{DR}}$ & V. ovatum & Marin Co., CA & AFLP & \\
\hline $\operatorname{Pr}-84^{\mathrm{DR}}$ & Soil & Marin Co., CA & AFLP & \\
\hline Pr- $86^{\mathrm{DR}}, \mathrm{CBS} 110541$, ATCC MYA-2440 & Arbutus menziessi & Marin Co., CA & AFLP & \\
\hline $\operatorname{Pr}-87^{\mathrm{DR}}$ & A. menziessi & Marin Co., CA & AFLP & \\
\hline $\operatorname{Pr}-88^{\mathrm{DR}}$ & Umbellularia californica & Sonoma Co., CA & AFLP & \\
\hline $\operatorname{Pr}-89^{\mathrm{DR}}$ & U. californica & Sonoma Co., CA & AFLP & \\
\hline Pr $-90^{\text {DR }}$ & Q. agrifolia & Marin Co., CA & AFLP & \\
\hline Pr-91 $1^{\text {DR }}$ & U. californica $^{\mathrm{N}}$ & Santa Cruz Co., CA & AFLP & \\
\hline Pr-97 DR, CBS110955 & Q. agrifolia & Napa Co., CA & AFLP & \\
\hline \multirow[t]{3}{*}{ Pr-102 ${ }^{\text {DR }}$, ATCC MYA-2949 } & Q. agrifolia & Marin Co., CA & AFLP, ITS & AY423280 \\
\hline & & & coxII & AY423303 \\
\hline & & & nad5 & AY423320 \\
\hline $\operatorname{Pr}-103^{\mathrm{DR}}$ & L. densiflora & Marin Co., CA & AFLP, ITS & AY423281 \\
\hline $\operatorname{Pr}-104^{\mathrm{DR}}$ & L. densiflora & Marin Co., CA & AFLP & \\
\hline $\operatorname{Pr}-105^{\mathrm{DR}}$ & L. densiflora & Marin Co., CA & AFLP, ITS & AY423282 \\
\hline Pr- $106^{\mathrm{DR}}, \mathrm{CBS} 110956$ & $U$. californica & Sonoma Co., CA & AFLP, ITS & AY423283 \\
\hline $\operatorname{Pr}-107^{\mathrm{DR}}$ & $U$. californica & Sonoma Co., CA & AFLP & \\
\hline $\operatorname{Pr}-108^{\mathrm{DR}}$ & Umbellularia californica & Sonoma Co., CA & AFLP, ITS & AY423284 \\
\hline $\operatorname{Pr}-110^{\mathrm{DR}}, \mathrm{CBS} 110542$ & U. californica & Marin Co., CA & AFLP & \\
\hline $\operatorname{Pr}-112^{\mathrm{DR}}$ & U. californica & Marin Co., CA & AFLP & \\
\hline $\operatorname{Pr}-113^{\mathrm{DR}}$ & $U$. californica & Marin Co., CA & AFLP & \\
\hline $\operatorname{Pr}-114^{\mathrm{DR}}$ & U. californica & Marin Co., CA & AFLP, ITS & AY423285 \\
\hline $\operatorname{Pr}-116^{\mathrm{DR}}$ & U. californica & Napa Co., CA & AFLP & \\
\hline $\operatorname{Pr}-120^{\mathrm{DR}}$ & L. densiflora & Mendocino Co., CA & AFLP, ITS & AY423286 \\
\hline Pr- $136^{\text {DR }}$, ATCC MYA-2441 & U. californica & Mendocino Co., CA & AFLP & \\
\hline $\operatorname{Pr}-146^{\mathrm{DR}}$ & L. densiflora & San Mateo Co., CA & AFLP & \\
\hline $\operatorname{Pr}-153^{\mathrm{DR}}$ & $U$. californica & Solono Co., CA & AFLP & \\
\hline $\operatorname{Pr}-156^{\mathrm{DR}}$ & L. densiflora & Curry Co., OR & AFLP & \\
\hline $\operatorname{Pr}-157^{\mathrm{DR}}$ & L. densiflora & Curry Co., OR & AFLP & \\
\hline Pr- $158^{\mathrm{DR}}, \mathrm{CBS} 110957$ & L. densiflora & Curry Co., OR & AFLP & \\
\hline $\operatorname{Pr}-159^{\mathrm{DR}}, \mathrm{CBS} 110543$ & L. densiflora & Curry Co., OR & AFLP, ITS & AF521574 \\
\hline Pr- $201 c^{D R}$ & Rhododendron sp. ${ }^{\mathrm{N}}$ & Santa Cruz Co., CA & AFLP & \\
\hline $\operatorname{Pr}-343^{\mathrm{DR}}, \operatorname{PrJL} 3.1^{\mathrm{DR}}$ & Sequoia sempervirens & Sonoma Co., CA & AFLP & \\
\hline Pr-345 DR $, \operatorname{PrJL} 3.5 .3^{\mathrm{DR}}, \mathrm{CBS} 110544$ & S. sempervirens & Sonoma Co., CA & AFLP, ITS & AF521576 \\
\hline
\end{tabular}


Table 1. (Cont.)

\begin{tabular}{|c|c|c|c|c|}
\hline Isolate number ${ }^{\mathrm{a}}$ & Host & Origin & Experiments & GenBank \\
\hline $\operatorname{Pr}-\mathrm{SDC} 21.6^{\mathrm{DR}}$ & S. sempervirens & Sonoma Co., CA & $\begin{array}{l}\text { AFLP, ITS } \\
\text { coxII } \\
\text { nad5 }\end{array}$ & $\begin{array}{l}\text { AF521577 } \\
\text { AY423304 } \\
\text { AY423321 }\end{array}$ \\
\hline $\operatorname{Pr}-3-74-1^{\text {EH }}$ & Pieris sp. ${ }^{\mathrm{N}}$ & Clackamas Co., CR & AFLP, ITS & AY423287 \\
\hline $\operatorname{Pr}-3-74-2^{\mathrm{EH}}$ & Viburnum bodnantense 'Dawn' & Clackamas Co., OR & AFLP & \\
\hline PDR $1282257^{\mathrm{CB}}$ & Camellia sasanqua 'Bonanza' ${ }^{\mathrm{N}}$ & Stanislaus Co., CA & AFLP & \\
\hline \multicolumn{5}{|l|}{$P$. ramorum $\left(\right.$ Europe) ${ }^{\mathrm{b}}$} \\
\hline $\mathrm{PD} 94 / 844^{\mathrm{PB}}, \mathrm{CBS} 101332$ & Rhododendron $\mathrm{sp}$. & The Netherlands & AFLP & \\
\hline $\mathrm{PD} 98 / 8 / 2627^{\mathrm{PB}}, \mathrm{CBS} 101331$ & Rhododendron sp. & The Netherlands & AFLP & \\
\hline PD 98/8/5233 ${ }^{\mathrm{PB}}, \mathrm{CBS} 101330$ & Viburnum sp. & The Netherlands & AFLP & \\
\hline PD $98 / 8 / 6285^{\mathrm{PB}}$, CBS101329 & Rhododendron sp. & The Netherlands & AFLP & \\
\hline PD $98 / 8 / 6743^{\mathrm{PB}}, \mathrm{CBS} 101328$ & Rhododendron $\mathrm{sp}$. & The Netherlands & AFLP & \\
\hline PD $98 / 8 / 6933^{\mathrm{PB}}, \mathrm{CBS} 101326$ & Rhododendron sp. & The Netherlands & AFLP & \\
\hline BBA $69082^{\text {SW }}$, CBS101548 & Rhododendron sp. 'Schneewolke' & Germany & AFLP & \\
\hline BBA $104 / 5^{\mathrm{SW}}, \mathrm{CBS} 101549$ & Recycling water in nursery & Germany & AFLP & \\
\hline BBA $9 / 95^{\mathrm{SW}}, \mathrm{CBS} 101553$ & R. catawbiense & Germany & AFLP & \\
\hline BBA $12 / 98^{\text {SW }}$, CBS101551 & R. catawbiense 'Grandiflorum' & Germany & $\begin{array}{l}\text { AFLP, ITS } \\
\text { coxII } \\
\text { nad5 }\end{array}$ & $\begin{array}{l}\text { AY } 423288 \\
\text { AY423305 } \\
\text { AY423322 }\end{array}$ \\
\hline BBA $13 / 99-1^{\mathrm{SW}}, \mathrm{CBS} 109279$ & Rhododendron sp. & Germany & AFLP & \\
\hline BBA $16 / 99^{\text {SW }}$, CBS109278 & $V$. bodnantense & Germany & AFLP & \\
\hline Phyram 1 EM & R. catawbiense 'Grandiflorum' & Mallorca, Spain & $\begin{array}{l}\text { AFLP, ITS } \\
\text { coxII } \\
\text { nad5 }\end{array}$ & $\begin{array}{l}\text { AY } 423289 \\
\text { AY423306 } \\
\text { AY } 423323\end{array}$ \\
\hline Phyram5 $5^{\text {EM }}$ & Rhododendron sp. & Mallorca, Spain & AFLP & \\
\hline CSL $1571^{\mathrm{AI}}$ & Viburnum tinus & England & AFLP & \\
\hline CSL $1599^{\mathrm{AI}}$ & R. ericaceae cv Cheer & Yorkshire, England & AFLP & \\
\hline CSL $1652^{\mathrm{AI}}$ & Rhododendron sp. & West Sussex, England & AFLP & \\
\hline PRI $508^{\mathrm{PB}}$ & $V$. bodnantense & Belgium & AFLP & \\
\hline \multicolumn{5}{|l|}{ P. lateralis } \\
\hline PL16 $6^{\mathrm{MG}}$ & Soil & Josephine Co., CA & $\begin{array}{l}\text { AFLP, ITS } \\
\text { coxII } \\
\text { nad5 }\end{array}$ & $\begin{array}{l}\text { AF521579 } \\
\text { AY423312 } \\
\text { AY423335 }\end{array}$ \\
\hline PL27 $7^{\mathrm{MG}}$ & Taxus brevifolia & Del Norte Co., CA & $\begin{array}{l}\text { AFLP, ITS } \\
\text { coxII }\end{array}$ & $\begin{array}{l}\text { AF521580 } \\
\text { AY423313 }\end{array}$ \\
\hline PL33 ${ }^{\mathrm{MG}}$ & Chamaecyparis lawsoniana & Del Norte Co., CA & $\begin{array}{l}\text { nad5 } \\
\text { AFLP, ITS } \\
\text { coxII } \\
\text { nad5 }\end{array}$ & $\begin{array}{l}\text { AY423336 } \\
\text { AF521581 } \\
\text { AY423314 } \\
\text { AY423337 }\end{array}$ \\
\hline \multicolumn{5}{|l|}{ P. cactorum } \\
\hline $\mathrm{P} 25^{\mathrm{DR}}, 6 \mathrm{~B} 2759^{\mathrm{GB}}$ & Prunus sp. & California & $\begin{array}{l}\text { ITS } \\
\text { nad5 }\end{array}$ & $\begin{array}{l}\text { AY } 423290 \\
\text { AY } 423324\end{array}$ \\
\hline \multicolumn{5}{|l|}{ P. cambivora } \\
\hline PDR198513 ${ }^{\mathrm{CB}}$ & Q. agrifolia & California & $\begin{array}{l}\text { ITS } \\
\text { coxII } \\
\text { nad5 }\end{array}$ & $\begin{array}{l}\text { AY423291 } \\
\text { AY423307 } \\
\text { AY423325 }\end{array}$ \\
\hline \multicolumn{5}{|l|}{ P. capsici } \\
\hline $\mathrm{P} 141^{\mathrm{DR}}, 3300^{\mathrm{GB}}$ & Lycopersicon esculentum & $\mathrm{N} / \mathrm{A}$ & $\begin{array}{l}\text { ITS } \\
\text { coxII } \\
\text { nad5 }\end{array}$ & $\begin{array}{l}\text { AY } 423292 \\
\text { AY423308 } \\
\text { AY423326 }\end{array}$ \\
\hline \multicolumn{5}{|l|}{ P. cinnamomi } \\
\hline $\mathrm{P} 2444^{\mathrm{MC}}(\mathrm{A} 2)$ & Persea americana & California & $\operatorname{nad} 5$ & AY423327 \\
\hline $\mathrm{P} 6379^{\mathrm{MC}}(\mathrm{A} 1)$ & Ananas comosus & Taiwan & $\begin{array}{l}\text { coxII } \\
\text { nad5 }\end{array}$ & $\begin{array}{l}\text { AY } 423309 \\
\text { AY423328 }\end{array}$ \\
\hline \multicolumn{5}{|l|}{ P. cryptogea } \\
\hline IMI 045168 & Lycopersicon esculentum & New Zealand & $\operatorname{nad} 5$ & AY423329 \\
\hline P. erythroseptica & & & & \\
\hline $355^{\mathrm{PT}}, \mathrm{LaQ}^{\mathrm{DL}}$ & Solanum tuberosum & Maine & $\begin{array}{l}\text { ITS } \\
\text { coxII } \\
\text { nad5 }\end{array}$ & $\begin{array}{l}\text { AY423293 } \\
\text { AY423310 } \\
\text { AY } 42333\end{array}$ \\
\hline \multicolumn{5}{|l|}{ P. gonapodyides } \\
\hline $393^{\mathrm{PT}}, \mathrm{NY} 353^{\mathrm{WW}}$ & Malus sylvestris & New York & $\begin{array}{l}\text { ITS } \\
\text { nad5 }\end{array}$ & $\begin{array}{l}\text { AY423294 } \\
\text { AY423331 }\end{array}$ \\
\hline
\end{tabular}


Table 1. (Cont.)

\begin{tabular}{|c|c|c|c|c|}
\hline Isolate number ${ }^{\mathrm{a}}$ & Host & Origin & Experiments & GenBank \\
\hline \multicolumn{5}{|l|}{ P. hibernalis } \\
\hline $379^{\mathrm{PT}}, 1895^{\mathrm{DR}}$, ATCC 64708 & Aquilegia vulgaris & New Zealand & $\begin{array}{l}\text { ITS } \\
\text { nad5 }\end{array}$ & $\begin{array}{l}\text { AY423295 } \\
\text { AY423332 }\end{array}$ \\
\hline $380^{\mathrm{PT}}, 1896^{\mathrm{DR}}$, ATCC 60352 & Citrus sinensus & Portugal & $\begin{array}{l}\text { ITS } \\
\text { nad5 }\end{array}$ & $\begin{array}{l}\text { AY } 423296 \\
\text { AY423333 }\end{array}$ \\
\hline \multicolumn{5}{|l|}{ P. ilicis } \\
\hline $4175 \mathrm{a}^{\mathrm{EH}}$ & Ilex aquifolium & Oregon & $\begin{array}{l}\text { ITS } \\
\text { coxII } \\
\operatorname{nad} 5\end{array}$ & $\begin{array}{l}\text { AY423297 } \\
\text { AY423311 } \\
\text { AY423334 }\end{array}$ \\
\hline \multicolumn{5}{|l|}{ P. megasperma } \\
\hline $309^{\mathrm{PT}}, 336^{\mathrm{PH}}$ & Pseudotsuga menziesii & Washington & $\begin{array}{l}\text { ITS } \\
\text { nad5 }\end{array}$ & $\begin{array}{l}\text { AY } 423298 \\
\text { AY423338 }\end{array}$ \\
\hline \multicolumn{5}{|l|}{ P. nemorosa } \\
\hline $\mathrm{P} 13^{\mathrm{DR}}$ & L. densiflora & California & $\begin{array}{l}\text { coxII } \\
\text { nad5 }\end{array}$ & $\begin{array}{l}\text { AY423315 } \\
\text { AY423339 }\end{array}$ \\
\hline \multicolumn{5}{|l|}{ P. nicotianae } \\
\hline $331^{\mathrm{PT}}, \mathrm{P} 1352^{\mathrm{MC}}$ & Nicotiana tabacum & North Carolina & $\begin{array}{l}\text { ITS } \\
\text { coxII } \\
\text { nad5 }\end{array}$ & $\begin{array}{l}\text { AY423299 } \\
\text { AY423316 } \\
\text { AY423340 }\end{array}$ \\
\hline \multicolumn{5}{|l|}{ P. palmivora } \\
\hline $\mathrm{P} 1-10^{\mathrm{DJM}}$ & Theobroma cacao & Costa Rica & $\begin{array}{l}\text { ITS } \\
\text { nad5 }\end{array}$ & $\begin{array}{l}\text { AY } 423300 \\
\text { AY423341 }\end{array}$ \\
\hline \multicolumn{5}{|l|}{ P. pseudosyringae } \\
\hline IFB PSEU $16^{\mathrm{TJ}}$ & Fagus sylvatica & Germany & $\begin{array}{l}\text { coxII } \\
\text { nad5 }\end{array}$ & $\begin{array}{l}\text { AY423317 } \\
\text { AY423342 }\end{array}$ \\
\hline $\mathrm{P} 40^{\mathrm{DR}}$ & Q. agrifolia & California & $\begin{array}{l}\text { coxII } \\
\text { nad5 }\end{array}$ & $\begin{array}{l}\text { AY } 423318 \\
\text { AY423343 }\end{array}$ \\
\hline \multicolumn{5}{|l|}{ P. sojae } \\
\hline $312^{\mathrm{PT}}$, ATCC 48068 & Glycine max & Wisconsin & $\begin{array}{l}\text { ITS } \\
\text { nad5 }\end{array}$ & $\begin{array}{l}\text { AY423301 } \\
\text { AY423344 }\end{array}$ \\
\hline \multicolumn{5}{|l|}{ P. syringae } \\
\hline PDR $115773 A^{C B}$ & Rhododendron sp. & California & $\begin{array}{l}\text { ITS } \\
\text { coxII } \\
\text { nad5 }\end{array}$ & $\begin{array}{l}\text { AY423302 } \\
\text { AY423319 } \\
\text { AY423345 }\end{array}$ \\
\hline
\end{tabular}

a CB, Cheryl Blomquist; PB, Peter Bonants; PH, Phil Hamm; MC, Mike Coffey; MG, Matteo Garbelotto; EH, Everett Hansen; AI, Alan Inman; DJM, Dave Mitchell; EM, Eduardo Moralejo; DR, Dave Rizzo; PT, Paul Tooley; TJ, Thomas Jung; WW, Wayne Wilcox.

b Due to quarantine regulations, lyophilized tissue (rather than cultures) of European isolates was obtained from sources listed in Acknowledgements.

N USA P. ramorum isolate from nursery.

the distribution of host species and very high mortality levels associated with infection of some hosts (e.g. tanoak), it is widely assumed that P. ramorum is exotic to North America. In an earlier study of 14 isolates from Germany and The Netherlands, AFLP analysis indicated these isolates formed a distinct cluster, representing a different lineage from those of the other eight Phytophthora species analysed, with small amounts of genetic variability within $P$. ramorum. These 14 isolates also shared identical ITS sequences and isozyme patterns of malate dehydrogenase and malic enzyme (Werres et al. 2001).

$P$. ramorum is heterothallic, requiring interaction of opposite mating types (A1 and A2) for sexual recombination. Until recently, all European isolates tested were shown to belong to the A1 mating type, and all American isolates tested were shown to belong to A2 (Werres et al. 2001, Moralejo \& Werres 2002, Brasier 2003, Werres \& Zielke 2003). These data, taken as a whole, suggest that $P$. ramorum may have been introduced separately into the USA and Europe. In 2002, the first European A2 isolate was collected from infested plant material in Belgium (Werres \& de Merlier 2003). In spring 2003, the first USA A1 isolates were identified during a national nursery survey in northern Oregon (Hansen et al. 2003). Subsequently more A1 isolates have been recovered from nurseries in Washington and British Columbia. In vitro (Clive $\mathrm{M}$. Brasier, pers. comm.) and in vivo (Werres \& Zielke 2003) matings have been successful between European A1 and USA A2 isolates. As well, USA A2 isolates from the wild and USA A1 isolates from nurseries have been mated successfully (Daniel Hüberli, pers. comm.).

An obvious consequence of sexual recombination in heterothallic Phytophthora species is the creation of new genotypes, although mixed mating type populations of some Phytophthora species (e.g. P. cinnamomi, $P$. infestans) have coexisted in the same location with 


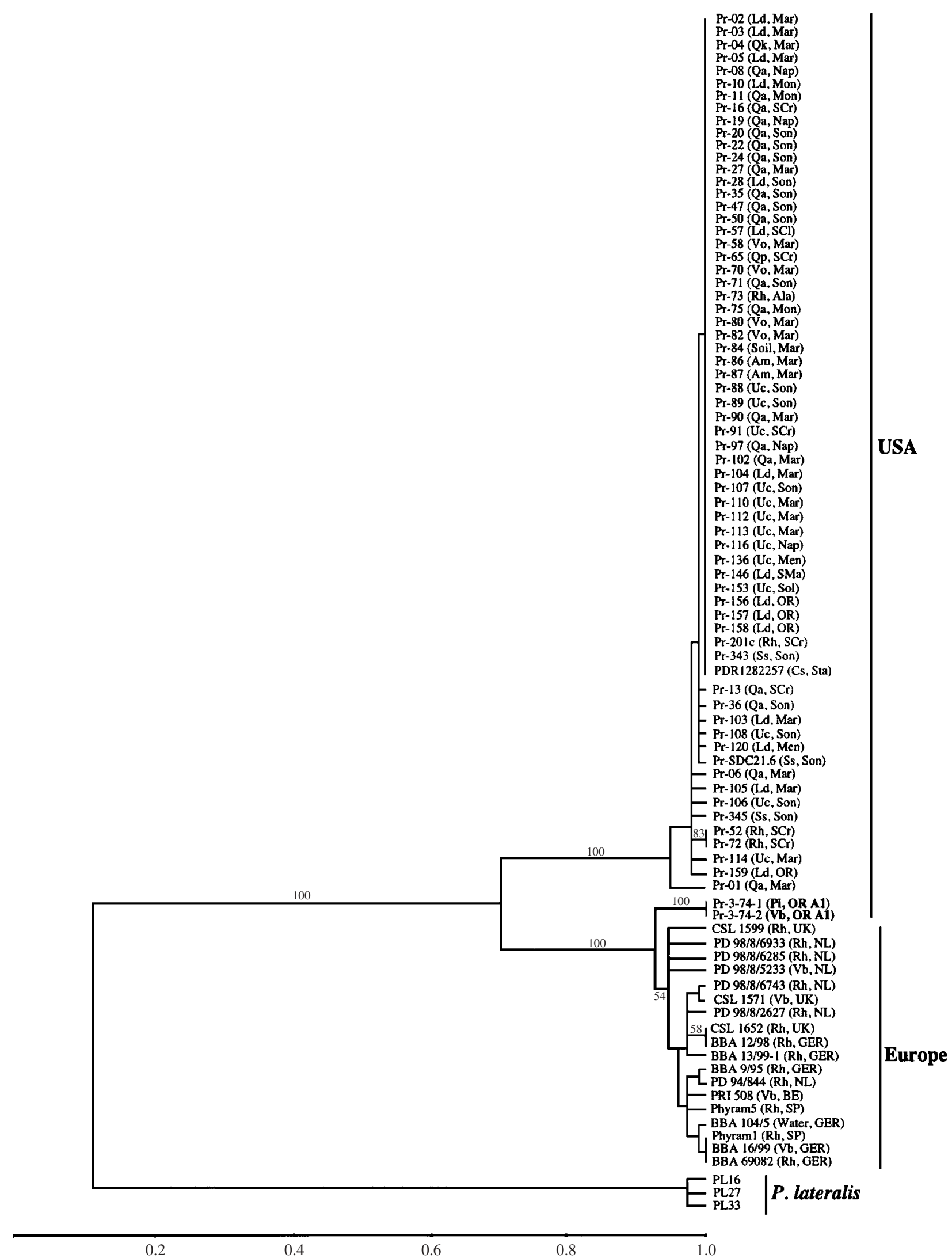

Fig. 1. Neighbour-joining tree obtained from $\mathrm{S}_{\mathrm{J}}$ similarity coefficients of 85 Phytophthora ramorum and three P. lateralis isolates generated from AFLP fingerprint data. The scale is proportion similarity, and numbers near branches indicate bootstrap values obtained from 1000 replicate analyses. Detailed isolate information (host and location) is located next to isolate ID on tree. Hosts: Am, Arbutus menziesii; Cs, Camellia sasanqua; Ld, Lithocarpus densiflora; Pi, Pieris spp.; Qa, Quercus agrifolia; Qk, Quercus kelloggii; Qp, Quercus parvula; Rh, Rhododendron spp.; Ss, Sequoia sempervirens; Uc, Umbellularia californica; Vo, Vaccinium ovatum; and Vb, Viburnum spp. USA locations: Ala, Alameda Co.; Mar, Marin Co.; 
extremely low levels, if any, of sexual reproduction (Goodwin et al. 1992, Linde et al. 1997, Dobrowolski et al. 2003). However, these recent discoveries of both mating types of $P$. ramorum in the USA and Europe bring up important questions regarding dispersal and genetic recombination mechanisms of this plant pathogen. The risk of introducing $P$. ramorum outside of its present range is of great concern. A better understanding of its origin, evolution and diversity is important for developing regulatory and disease management strategies. Information on the origin of this pathogen could also provide an effective basis for the search and application of disease resistance in economically and ecologically important hosts species.

The work reported here has a number of objectives related to the overall aim of understanding the origin and genetic variability of $P$. ramorum, and its genetic placement within the genus Phytophthora. Our first objective was to characterize the genetic structure of $P$. ramorum populations present in the USA and Europe. This was done by examining a broad range of isolates with AFLP fingerprinting to determine if recombination is taking place within and between populations, and if population subdivisions exist based on geography or host species. Our second objective was to provide a better phylogenetic understanding of this species within the genus Phytophthora by inferring gene phylogenies for numerous Phytophthora species from three different loci: portions of the nuclear rDNA ITS region, and portions of the mitochondrially-encoded NADH dehydrogenase subunit 5 (nad 5) and cytochrome oxidase subunit II (cox II) genes.

\section{MATERIALS AND METHODS}

\section{Isolates}

Isolates of Phytophthora ramorum were chosen to represent a broad range of geographic locations and hosts (Table 1). 67 P. ramorum isolates from the USA and 18 from Europe, along with three $P$. lateralis isolates used as an outgroup species, were analysed with AFLP. Other Phytophthora species were used to generate sequence data for phylogenetic analysis (Table 1). Isolates were maintained on $\mathrm{V} 8$ agar at $15-20{ }^{\circ} \mathrm{C}$, depending on species. Cultures used in this study are currently stored under liquid nitrogen in the Department of Plant Pathology, University of California, Davis. Representative voucher cultures have also been deposited with ATCC and CBS (Table 1).

\section{DNA isolation}

Isolates were grown in potato dextrose broth on a rotary shaker at room temperature for approx. $10 \mathrm{~d}$.
Genomic DNA was isolated from $75 \mathrm{mg}$ of lyophilized mycelium using the following modified CTAB extraction procedure. Lyophilized tissue was pulverized with glass beads in a FastPrep ${ }^{\circledR}$ instrument (Bio101, Carlsbad, CA) for $5 \mathrm{~s}$ at $4000 \mathrm{rpm}$. Pulverized tissue was incubated in $500 \mathrm{ml} \mathrm{CTAB}$ on dry ice for $2 \mathrm{~min}$, and then thawed at $75^{\circ}$ for $2 \mathrm{~min}$. DNA was purified in phenol:chloroform:isoamyl alcohol (25:24:1), further cleaned by using the Geneclean ${ }^{\circledR}$ Turbo Nucleic Acid Purification kit (Qiagen, Valencia, CA) according to the manufacturer's instructions, and eluted in $30 \mu 1$ ultra-pure water. DNA extracts were stored at $-20^{\circ}$.

\section{DNA amplification}

Templates of the nad 5 gene were amplified for sequencing by PCR using primers P1bfwd (5'-ATGCTATGGAAGGTCCTACA-3') and P1brev (5'-AGGTAGTATACGTCTTAAAC-3') as previously described (Jung et al. 2003), and resulted in a 388 bp fragment. Templates of the cox II gene were amplified using primers FM 35 (5'-CAGAACCTTGGCAATTAGG$\left.3^{\prime}\right)$ and FM 58 (5'-CCACAAATTTCACTACATTGA-3') as previously described (Martin 2000), resulting in a $540 \mathrm{bp}$ fragment. ITS amplification was performed with primers ITS1 and ITS4 (White et al. 1990) as previously described (Bonants et al. 1997), resulting in a $c a$ 910-940 bp fragment depending on the species sequenced. All PCR products were sequenced with initial amplification primers on an ABI 3100 genetic analyzer (Applied Biosystems, Foster City, CA).

\section{AFLP analysis}

AFLP reactions were performed as described by Vos $e t$ al. (1995) with slight modifications, using the AFLP core reagent kit (Invitrogen, Carlsbad, CA). AFLP ${ }^{\circledR}$ technology is covered by patents and patent applications owned by Keygene. Genomic DNA (250 ng) was digested with $1.25 \mathrm{U}$ each of the restriction enzymes EcoRI and MseI for $2 \mathrm{~h}$ at $37^{\circ}$ in reaction buffer supplied with the kit. Adapters were ligated to restriction fragments in a total volume of $25 \mu \mathrm{l}$ for $2 \mathrm{~h}$ at $20^{\circ}$ using $0.5 \mathrm{U}$ of T4 DNA ligase. Ligation products were diluted 1:9 with ultra-pure water. Following ligation, DNA was first amplified by PCR using nonselective EcoRI (E00) (5'-GACTGCGTACCAATTC-3') and MseI (M00) (5'-GATGAGTCCTGAGTAA-3') primers. Each reaction mixture contained buffer $(10 \mathrm{~mm}$ Tris/ $\mathrm{HCl} \mathrm{pH} 8.3,50 \mathrm{~mm} \mathrm{KCl}, 1.5 \mathrm{~mm} \mathrm{MgCl}_{2}$ ), $50 \mu \mathrm{M}$

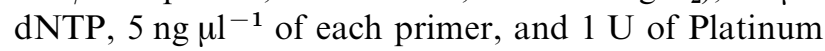
Taq DNA polymerase (Invitrogen). PCR was performed in an iCycler thermocycler (Bio-Rad

Men, Mendocino Co., Mon, Monterey Co.; Nap, Napa Co.; Sol, Solono Co.; Son, Sonoma Co.; SMa, San Mateo Co.; SCr, Santa Cruz Co.; SCl, Santa Clara Co.; Sta, Stanislaus Co.; OR, Oregon. European locations: BE, Belgium;

GER, Germany; NL, The Netherlands; SP, Spain; and UK, United Kingdom. See Table 1 for additional isolate details. 
Laboratories, Hercules, CA) under the following conditions : 20 cycles of $30 \mathrm{~s}$ at $94^{\circ}, 1 \mathrm{~min}$ at $56^{\circ}$, and $1 \mathrm{~min}$ at $72^{\circ}$. The amplification products were diluted $1: 30$, and $5 \mu \mathrm{l}$ was used as a template for selective PCR. Based on the results from an initial screening of multiple primer combinations, four informative pairs of selective-base primers were used in the analysis: $(\mathrm{E} 00-\mathrm{AC})+(\mathrm{M} 00-\mathrm{AC}),(\mathrm{E} 00-\mathrm{TC})+(\mathrm{M} 00-\mathrm{AG}),(\mathrm{E} 00-$ $\mathrm{GC})+(\mathrm{M} 00-\mathrm{AC})$, and $(\mathrm{E} 00-\mathrm{GG})+(\mathrm{M} 00-\mathrm{CC})$. Selective PCR conditions were described as above, except using $5 \mathrm{ng}$ of the EcoRI primer (labelled with FAM at the 5' end), $15 \mathrm{ng}$ of the $M \mathrm{se}$ I primer, and $5 \mathrm{mM} \mathrm{MgCl}_{2}$. The cycling profile was as follows: 13 cycles of $30 \mathrm{~s}$ at $94^{\circ}, 30 \mathrm{~s}$ at $65^{\circ}$ (with annealing temperature lowered $0.7^{\circ}$ each cycle), and $1 \mathrm{~min}$ at $72^{\circ}$, followed by 23 cycles of $30 \mathrm{~s}$ at $94^{\circ}, 30 \mathrm{~s}$ at $56^{\circ}$, and $1 \mathrm{~min}$ at $72^{\circ}$. Selective amplification products were diluted $1: 10$ with deionized formamide, denatured for $5 \mathrm{~min}$ at $95^{\circ}$, and placed on ice before processing. AFLP fragments were sized by capillary electrophoresis on an automated ABI 3100 genetic analyzer using the molecular standard GeneScan-500 ROX and GeneScan 3.1.2 software (Applied Biosystems). Electropherograms were scored manually and side by side for the presence (1) or absence $(0)$ of bands of the same apparent size, and only fragments (ranging in size from 70-600 bp) that could be scored unambiguously were analysed. AFLPs of most $P$. ramorum isolates were repeated starting at the ligation step to ensure reproducibility.

Data from all primer combinations were combined and the resulting binary matrix was transformed into a distance matrix $(1-$ similarity coefficient $)$ using the Jaccard coefficient of similarity (Jaccard 1908) with the program package LE PROGICEL R (version 4; Casgrain \& Legendre 1999), which measures the proportion of shared bands. This transformation was utilized to reduce error caused by the dominant nature of the AFLP markers. The matrix was translated into a distance cladogram with the neighbour-joining algorithm in MEGA, version 2.1 (Kumar et al. 2001). The resulting tree was rooted using AFLP profiles of three isolates of $P$. lateralis, the closest known relative of $P$. ramorum based on ITS sequences (Rizzo et al. 2002). Bootstrap values of branch points were generated in PAUP, version 4.0b10 (Swofford 2002) using 1000 replicates.

\section{MultiLocus analysis}

In order to test for reproductive mode (i.e. clonal or recombining), a clone-corrected AFLP binary dataset of the two separate geographic populations, as well as the entire selection of isolates, was analysed for linkage disequilibrium using a modified index of association $\left(I_{\mathrm{A}}\right)$ equation in the software program MultiLocus V.1.2.2. (Agapow \& Burt 2001). Significance of $I_{\mathrm{A}}$ was determined by randomization (1000 times) procedures by comparing the observed value of $I_{\mathrm{A}}$ to that expected under the null hypothesis of complete panmixis.

\section{Phylogenetic analysis}

Published sequences and alignments of other Phytophthora species were downloaded from GenBank and TreeBASE, aligned with generated sequences using the multialignment program Sequencher 4.1.2, and manually optimized using the program Se-Al version 2 (Rambaut 1996). Phylogenetic analyses were performed using PAUP* version 4.0b10 (Swofford 2002). For the ITS dataset, nucleotide sites were equally weighted and gaps were treated as missing data. Bases 94 to 661 of the cox II and 731 to 1119 of the nad 5 genes were used for phylogenetic analysis. For all three datasets, phylogenetic relationships among Phytophthora spp. were inferred with maximum-parsimony (MP) analysis by performing heuristic searches with MULPARS on, steepest-descent off, random addition of sequences, and tree bisection reconnection (TBR) branch swapping. Support for internal branches was obtained by bootstrap analysis using 1000 replications (Felsenstein 1985). All sequences and alignments generated in this study have been deposited in GenBank (Table 1) and TreeBASE (S1036), respectively.

\section{RESULTS \\ AFLP analysis}

67 isolates from the USA were analysed with AFLPs, originating from 11 California (Alameda, Marin, Mendocino, Monterey, Napa, San Mateo, Santa Clara, Santa Cruz, Solono, Sonoma, and Stanislaus) and two Oregon (Curry and Clackamas) counties. Stanislaus and Clackamas County isolates were from nurseries outside the natural range of Phytophthora ramorum. The 18 European isolates originated from five countries: Belgium, Germany, The Netherlands, the UK, and Spain. The AFLP fingerprints from all four primer combinations resulted in 269 bands that could be unambiguously scored, of which $74(27.5 \%)$ were polymorphic among $P$. ramorum isolates. There were differences in the numbers of AFLP loci produced by each of the different primer pairs, which presumably reflect differences in sequence composition in the genome. All isolates that did not differ by at least one fragment were considered the same AFLP genotype. Dendrograms constructed from each individual AFLP primer combination were concordant, and only differed in degree of resolution (data not shown). Fingerprints from all four primer combinations were combined and used to generate a dendrogram (Fig. 1). A high degree of AFLP similarity among all $P$. ramorum isolates was observed,

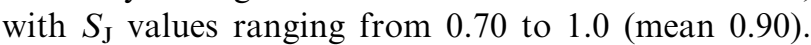
In comparison, a low degree of AFLP similarity was observed between $P$. ramorum and $P$. lateralis isolates,

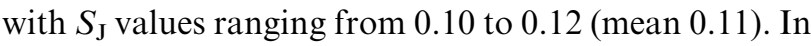
the USA and European populations, $S_{\mathrm{J}}$ varied from 0.94 to 1.0 (mean 0.99 ) and 0.91 to 1.0 (mean 0.96 ), respectively. 


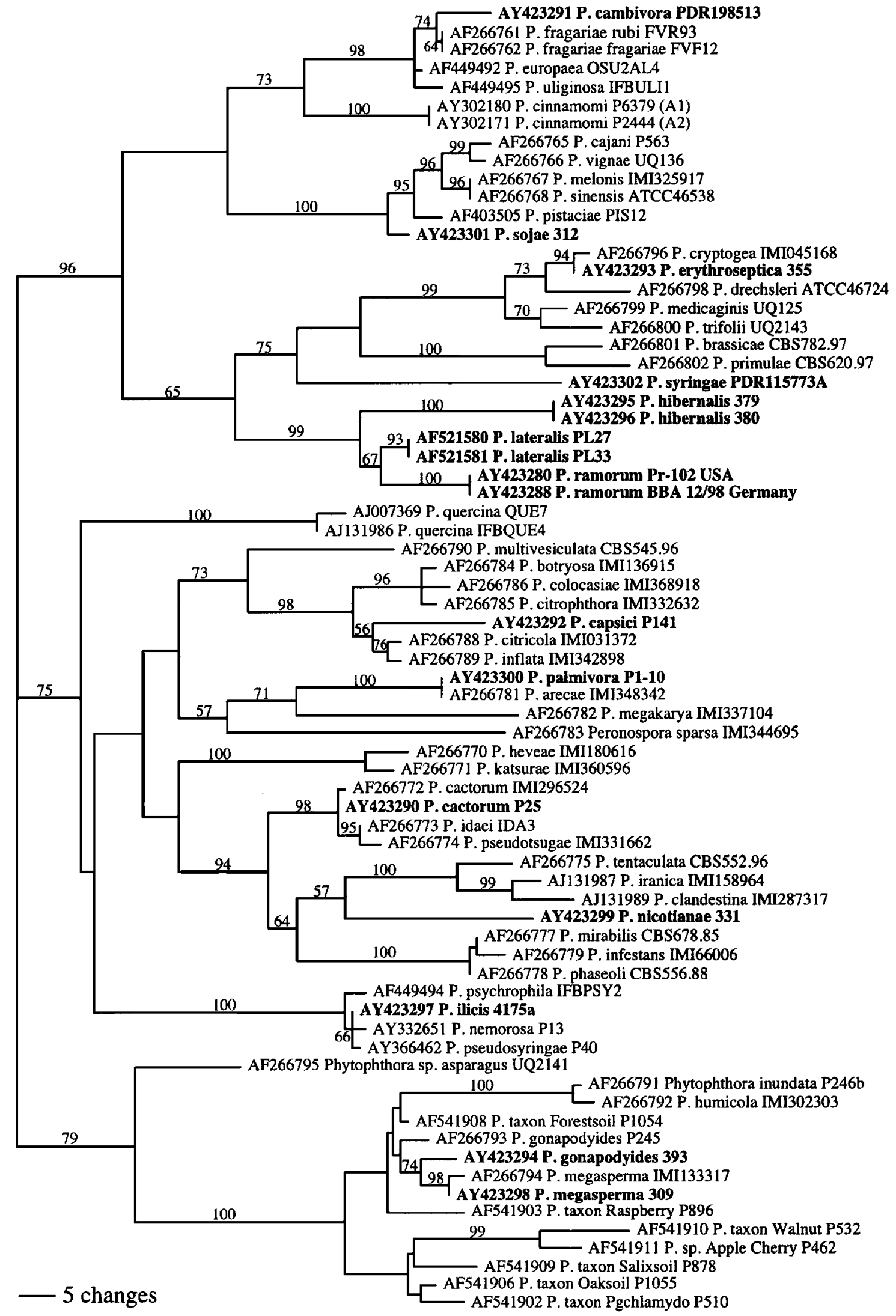

Fig. 2. Phylogenetic relationships among Phytophthora species using ITS rDNA sequence data, based on maximum parsimony inferred by a heuristic tree search. Numbers near branches are the percentage of the trees from bootstrap analysis that support the observed topography (values above $50 \%$ indicated). This is one of 1891 trees with the shortest length. Of the 878 total characters, 503 were constant, 63 were variable and parsimony-uninformative, and 312 were parsimony-informative. Tree length $=1075$, consistency index $(\mathrm{CI})=0.487$, homoplasy index $(\mathrm{HI})=0.513$, retention index $=0.832$. The sequences of taxa in bold were generated for this study. 


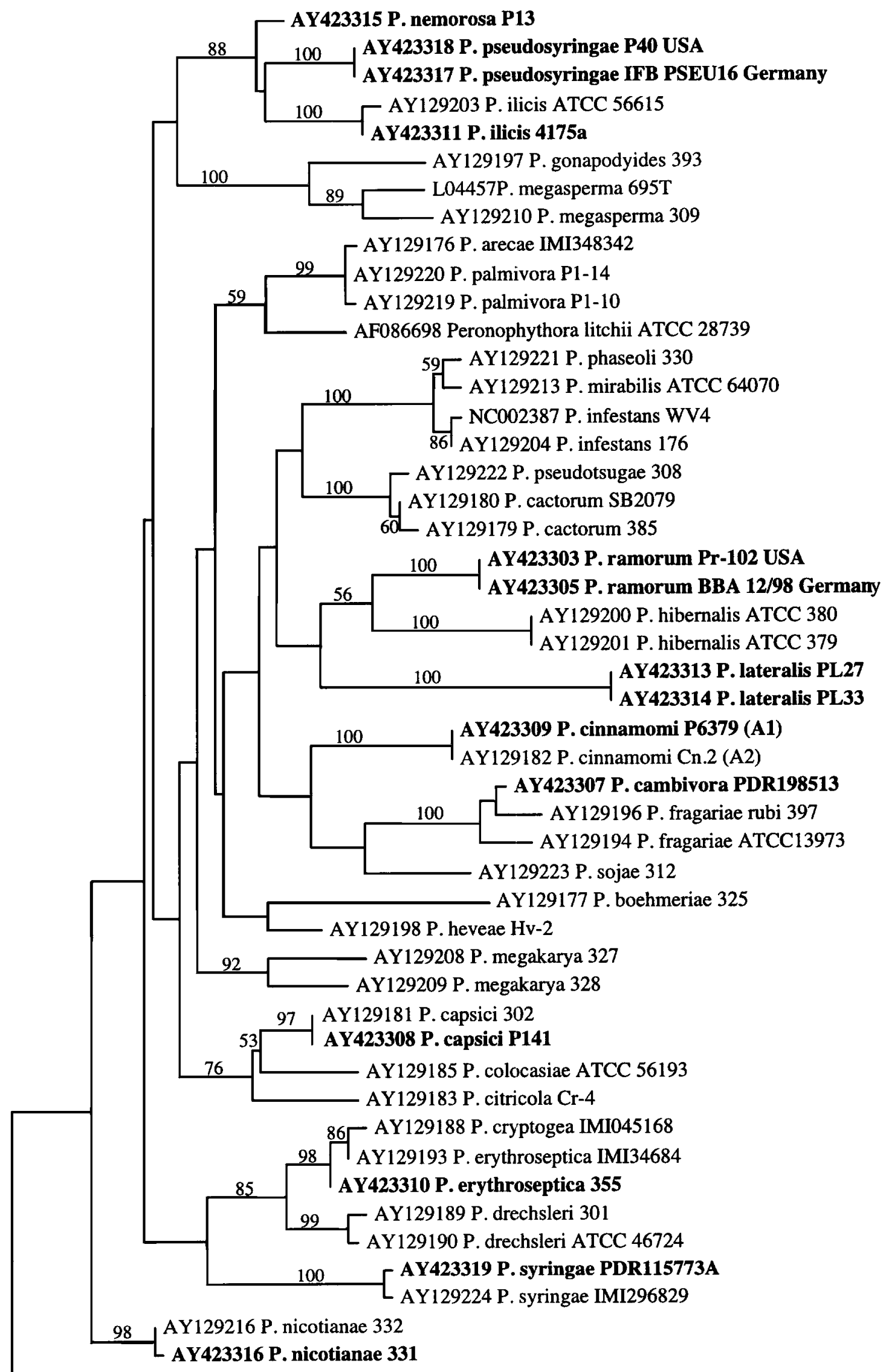

AF196579 Pythium aphanidermatum 1987-61

5 changes

Fig. 3. For legend see opposite page. 
With the exception of the two A1 Oregon nursery isolates Pr-3-74-1 and Pr-3-74-2, AFLP analysis showed a clear distinction between USA and European isolates (100\% bootstrap support). The two Oregon nursery isolates clustered within the European population, as reported by Hansen et al. (2003). In all, 31 distinct AFLP genotypes were identified among all 85 $P$. ramorum isolates. 16 AFLP fingerprints were observed among USA isolates, with a single clone genotype dominating the population and representing over $75 \%$ of all USA isolates. This genotype was widely distributed and represented isolates from all 11 California counties, as well as Curry County, Oregon. Unique USA genotypes were only observed once, except with isolates Pr-52 and Pr-72 (from the same nursery in Santa Cruz County, CA) sharing the same AFLP fingerprint. Among the 18 European isolates analysed, 15 AFLP fingerprints were observed. Most European genotypes were unique, however two AFLP types recurred in different countries. Isolates Phyram1 (Spain), BBA 16/99 (Germany) and BBA 69082 (Germany), and isolates CSL 1652 (UK) and BBA 12/98 (Germany) shared the same AFLP fingerprints. Isolates BBA 16/99 and BBA 69082 had identical AFLP profiles, whereas in a previous AFLP study using different enzyme and primer combinations they were shown to be distinct (Werres et al. 2001).

\section{MultiLocus analysis}

The distribution of AFLP bands among all isolates, as well as among the two separate Phytophthora ramorum geographic populations, was analysed to determine whether there was any evidence that recombination may have affected the population structure over the time and area represented by the samples. The index of association, $I_{\mathrm{A}}$, has an expected value of zero if there is no association of alleles at unlinked loci as assumed in a randomly mating population, therefore high withinpopulation levels of linkage disequilibria are expected in largely clonal species. At the species level, the observed $I_{\mathrm{A}}$ value $\left(I_{\mathrm{A}}=19.297\right)$ for all $P$. ramorum isolates was significantly higher $(P=<0.001)$ than the $I_{\mathrm{A}}$ calculated from 1000 artificially recombined datasets. Therefore these results do not confirm recombination events among the entire selection of isolates; i.e. results suggest the two geographic populations are not recombining. However, when populations were considered separately, the observed $I_{\mathrm{A}}$ across loci in the USA population $\left(I_{\mathrm{A}}=-0.126903\right)$ fell within the distribution for randomized datasets, indicating no significant correlation $(P=0.607)$ of alleles across loci. Likewise, the observed $I_{\mathrm{A}}$ across loci in the European population $\left(I_{\mathrm{A}}=0.420827\right)$ fell within the distribution for randomized datasets, also indicating no significant correlation $(P=0.117)$ of alleles across loci. Hence, the null hypothesis of recombination within each individual geographic population could not be rejected. Since the recent Oregon nursery A1 isolates were determined to be of separate and distinct origins than other USA isolates (Hansen et al. 2003), they were not considered part of the USA or European population and were excluded from the individual population MultiLocus analyses.

\section{Sequence analysis}

The ITS, cox II and nad 5 regions of Phytophthora ramorum isolates representing the 31 different AFLP genotypes were sequenced to determine if they had any detectable sequence polymorphisms. However, all sequenced USA and European isolates had identical ITS, cox II and nad 5 sequences and showed no nucleotide variation. ITS rDNA trees, constructed by a heuristic search based on maximum parsimony, placed P. ramorum within ITS subclade 8 a (Cooke et al. 2000) along with $P$. lateralis and $P$. hibernalis with strong bootstrap support; $P$. ramorum was more distantly related to species such as $P$. syringae, $P$. drechsleri, and P. cryptogea (Fig. 2). The topology of the 1891 most parsimonious trees generated by the heuristic search were almost identical except for branch lengths, and were similar to a majority-rule consensus tree. Of the 878 nucleotides analysed, ITS sequences differed by 11 nucleotides between $P$. ramorum and $P$. lateralis, and by 45 nucleotides between $P$. ramorum and $P$. hibernalis.

No gaps were observed in either mtDNA-encoded cox II and nad 5 sequence alignment, and all information for parsimony analysis was inferred from base pair substitutions. Most of the major nodes were unresolved for the cox II and nad 5 gene trees, although branches for some clades and species groupings had moderate to strong bootstrap support (Figs 3-4). Phylogenetic relationships within the clades described by ITS were mostly lost within trees produced by mtDNA sequences; these trees were not largely discordant with ITS, but less resolved. The three species $P$. ramorum, $P$. lateralis and $P$. hibernalis appeared as a cluster of related species; however, there was low bootstrap support for such relationships due to this loss of resolution. No intraspecific variation was observed in these gene regions for the two related species

Fig. 3. Phylogenetic relationships among Phytophthora species using cox II DNA sequence data, based on maximum parsimony inferred by a heuristic tree search. Numbers near branches are the percentage of the trees from bootstrap analysis that support the observed topography (values above $50 \%$ indicated). This is one of 24 trees with the shortest length. Of the 568 total characters, 394 were constant, 39 were variable and parsimony-uninformative, and 135 were parsimonyinformative. Tree length $=531$, consistency index $(\mathrm{CI})=0.482$, homoplasy index $(\mathrm{HI})=0.518$, retention index $=0.720$. The sequences of taxa in bold were generated for this study. 


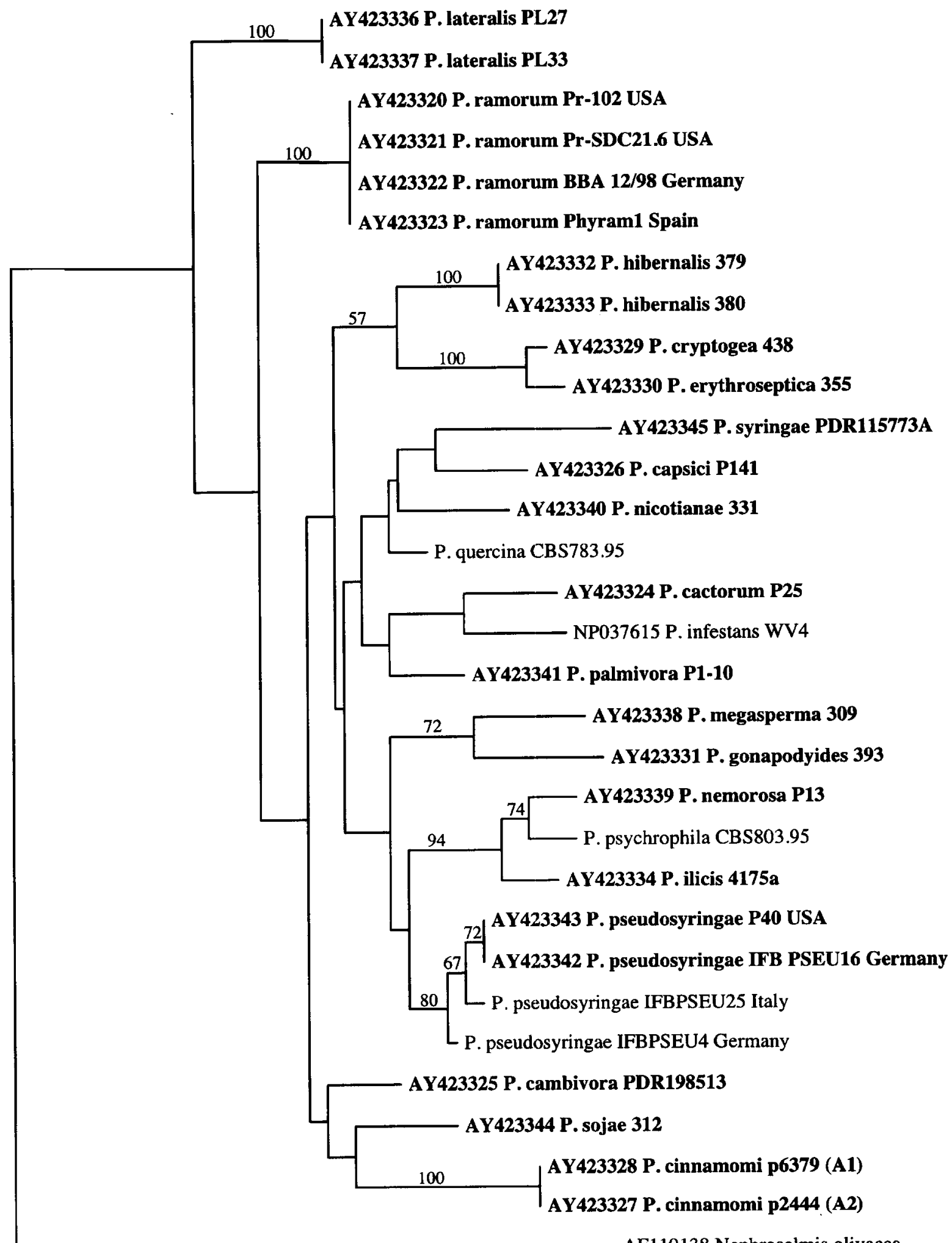

AF110138 Nephroselmis olivacea

\section{5 changes}

Fig. 4. Phylogenetic relationships among Phytophthora species using nad 5 DNA sequence data, based on maximum parsimony inferred by a heuristic tree search. Numbers near branches are the percentage of the trees from bootstrap analysis that support the observed topography (values above $50 \%$ indicated). This is the single most parsimonious tree. Of the 388 total characters, 243 were constant, 65 were variable and parsimony-uninformative, and 80 were parsimony-informative. Tree length $=383$, consistency index $(\mathrm{CI})=0.525$, homoplasy index $(\mathrm{HI})=0.475$, retention index $=0.631$. The sequences of taxa in bold were generated for this study. 
$P$. hibernalis and P. lateralis. Phylogenetic analysis of all three datasets combined was not performed, as the results of a partition homogeneity test in a previous study suggested that combining datasets from ITS and cox II sequences may not be justifiable (Martin \& Tooley 2003).

\section{DISCUSSION}

Our AFLP profiles demonstrate a low level of genetic variation in both USA and European Phytophthora ramorum populations. Most of the variation among isolates within each population was due to a very limited number of differences (absence or presence) in fragment profiles. The greatest differences were between the USA and European populations, which clustered into two distinct phylogenetic lineages. When AFLP similarity within individual populations from each continent was calculated, values were much higher than those reported for sexually reproducing populations (Péros, Berger \& Lahogue 1997, Lamour \& Hausbeck 2001), suggesting that most of the AFLP variability within the species is due to continental provenance rather than to true population subdivision. Overall similarity of banding patterns between the two populations confirms they belong to the same species and are distinct from the closely related species $P$. lateralis. In addition, all sequenced USA and European isolates of $P$. ramorum had identical ITS, cox II, and nad 5 sequences. This indicates a high degree of relatedness and common ancestry within this species. It may mean that $P$. ramorum has more recently evolved or that the amplified regions are highly conserved within its genome. Some variability within Phytophthora species was observed in the mtDNA gene regions; hence such loci could be useful for studies investigating intraspecific variation (Jung et al. 2003, Martin \& Tooley 2003). The multiple gene phylogenies generated in our study are limiting because they do not provide high resolution of genetic relationships among the close relatives of $P$. ramorum. However, these phylogenies support the view that $P$. ramorum shares recent common ancestors with, but is distinct from $P$. lateralis and $P$. hibernalis.

In the USA, a single AFLP genotype comprised $75 \%$ of the isolates and was recovered throughout the known natural geographic range of the pathogen. This suggests a primarily clonal USA population structure of $P$. ramorum. No correlation was demonstrated between host and AFLP genotype, supporting the idea of host non-specificity, which has also been suggested by previous inoculation studies (Garbelotto et al. 2003). In comparison to the USA, European isolates clustered as a number of unique, but closely related, lineages. The higher amounts of intraspecific variation in the European population suggest the introduction of multiple strains into Europe, a longer residence time in Europe, or different selection pressures (e.g. different conditions in European nurseries compared to wild land settings in USA). There were no correlations between geography and AFLP genotype within the European population. This lack of geographic structuring may be due to the relatively recent introduction of this pathogen into Europe and(or) to the humanrelated gene flow from frequent movement of $P$. ramorum on infected plant material. The probable role of plant trade pathways in the creation of an 'artificial' panmictic population at the continental level is highlighted by the observation that two AFLP types were found more than once within Europe, and in different countries.

In contrast with our AFLP results, recent phenotypic studies of $P$. ramorum indicate that USA isolates are more variable in morphology, growth rate and virulence than European isolates (Brasier et al. 2002, Pogoda \& Werres 2002, Brasier 2003). In addition, a recent study detected differences in sporangial morphology between isolates from the USA and Europe (D. Hüberli \& M.G., unpubl.). The lack of correlation among phenotypic and genotypic variation has been demonstrated in other Phytophthora species (Dudzinski, Old \& Gibbs 1993, Abu-El Samen, Secor \& Gudmestad 2003). Phenotypic variation within a molecular clone was also reported for P. cinnamomi in Western Australia (Hüberli et al. 2001). The continuous range of variability in phenotypic characters rather than discrete groupings suggests such traits may be multigenic; consequently, an AFLP or microsatellite clone should not be considered a genetic clone (Brasier 2003). It is possible that the adaptive genes conferring such fitness variables and those associated with our AFLP fingerprints may be evolving at different rates (Brasier 2003).

One potential hypothesis to explain the source of the limited AFLP variation in P. ramorum populations is that the level of genetic variation seen within each geographic population has arisen via asexual mechanisms. Linkage disequilibrium was detected by computation of the $I_{\mathrm{A}}$ when all isolates were treated as a single population. Within the limits of the isolates available for this study, this result strongly suggests that recombination has not been occurring between the two continents, and hence between the two mating types. Alternatively, the genetic variation seen within each geographic population may have arisen via asexual mechanisms, such as mutation and(or) mitotic recombination; we were unable to exclude this possibility. Mitotic crossing-over produces much lower levels of genetic variation in comparison to sexual recombination. When pairwise Jaccard similarity values for the AFLP data were extracted in all combinations and plotted by geographic population, frequency distribution was not informative (data not shown). Due to the high similarity among isolates, the distribution of pairwise data appeared as a tall, narrow peak rather than a unimodal or bimodal Gaussian curve (Redecker et al. 2001), suggesting that genotypes in each population were not generated by true recombination, but by other means as suggested above. 
Evidence of mitotic recombination in Phytophthora species has been previously reported (Sansome 1980, Goodwin, Cohen \& Fry 1994, Abu-El Samen, Secor \& Gudmestad 2003, Dobrowolski et al. 2003) and could explain the slight variations observed in our AFLP profiles within each population. P. ramorum is known to rapidly reproduce asexually through the formation of large numbers of sporangia, which either germinate directly or differentiate into motile zoospores. A recent study reported considerable levels of inherent genetic variability among single-zoospore isolates of $P$. infestans asexually derived from the same parent culture (Abu-El Samen, Secor \& Gudmestad 2003) and implicated mitotic recombination as a possible cause.

Another hypothesis is that sexual recombination has generated the observed AFLP variation. In the populations surveyed, the present data cannot rule out the possibility of sexual recombination in $P$. ramorum populations, but indicate that sexual recombination is restricted, and highlighted by mating type segregation within each population. In a population where sexual reproduction is frequent, the two mating types are expected to occur in similar numbers (Anagnostakis 1988), unless one mating type demonstrates reduced fitness. The underlying equilibrium among loci within each population could be indicative of earlier recombination events. It is also possible that $P$. ramorum exhibits an 'epidemic' population structure (Maynard Smith et al. 1993) within the USA, meaning that a highly successful individual from an originally heterogeneous sexual population increases rapidly, subsequently producing an epidemic clone, possibly due to clonal or episodic selection (Brasier 1995). It should be noted, however, that in populations with low genetic diversity it is not possible to estimate the importance of sexual and asexual reproduction with DNA fingerprints alone (Hoegger et al. 2000). Codominant markers, including microsatellite loci, should provide a better understanding of the contribution of mitotic recombination to overall population structure of $P$. ramorum populations.

The predominance of a single mating type and low levels of genotypic diversity within each geographic population support the hypothesis that $P$. ramorum was recently introduced into both North America and Europe. Lower geographical population structure and overall genetic diversity is expected for a disease that has emerged due to a recent introduction or translocation (Morehouse et al. 2003). However, the observed phenotypic differences in isolates, in conjunction with mating type segregation, support the hypothesis of separate introductions onto both continents from a third, as yet unknown, location. The existence of $P$. ramorum elsewhere is not documented, although a thorough search of hosts on other continents has not been conducted. A direct European-North American route, followed by differential selection of phenotypes on the two individual continents is also possible. The establishment of $P$. ramorum on both continents is most likely due to increased movement of plants from the wild into cultivation, and from one part of the world to another through the international nursery trade.

Opportunities for sexual recombination and gene flow between the A1 and A2 types have probably been limited in North America and Europe, as it appears that these mating types have been geographically separated until recently, with no current evidence of gene flow between the two populations. The recent discovery that A1 isolates in an Oregon nursery located outside the known natural range of $P$. ramorum, represented by isolates Pr-3-74-1 and Pr-3-74-2 in our analyses, share very similar AFLP profiles with European isolates, as supported by Hansen et al. (2003), indicates similar origins. Although introduction from a third location cannot be excluded, a European-North American pathway for movement of these genotypes is also possible. This possibility, combined with the evidence of genetically and phenotypically distinct European and North American lineages supported by our results and other studies, highlights the need for regulatory control of plant trade between different continents.

A centre of origin has been unequivocally demonstrated for only a few Phytophthora species (Tooley, Fry \& Villareal Gonzalez 1985, Zentmyer 1988). The origin of many presumed exotic species of Phytophthora is unknown. For example, $P$. lateralis is assumed to be an introduced forest pathogen in the USA but more than $80 \mathrm{yr}$ after it was first identified, the origin of this pathogen is still undetermined (Hansen et al. 2000). Although represented by only one species in North America, 100-200 species of the genus Lithocarpus are distributed throughout eastern and southern Asia and Indomalaysia (Little 1979). Several other reported hosts of $P$. ramorum have their origins in Asia, including Rhododendron and Viburnum, thus an Asiatic origin for this plant pathogen seems plausible. More survey and population studies are required before the origin of $P$. ramorum can be determined. With a better understanding of the epidemiology, evolution and population biology of $P$. ramorum, regulatory solutions can be developed for the continued spread and management of the disease in sensitive uninfected forests and commercial nurseries.

\section{ACKNOWLEDGEMENTS}

Funding for this research was provided by the Gordon and Betty Moore Foundation and the Pacific Southwest Research Station, USDA Forest Service. We are very grateful to LeAnn Douhan, Cheryl Blomquist and Everett Hansen for providing USA Phytophthora ramorum isolates for study; and to Arthur de Cock (Centraalbureau voor Schimmelcultures), Alan Inman (Central Science Laboratory, York), Eduardo Moralejo (Mediterranean Institute for Advanced Studies) and Sabine Werres (Institute for Plant Protection in Horticulture, Braunschweig) for providing foreign $P$. ramorum tissue. We are also thankful for isolates of other Phytophthora species provided by Mike Coffey, Everett Hansen, 
Thomas Jung and Paul Tooley. We also thank Austin Burt for help with interpretation of the MultiLocus data, and Sabine Werres for comments on our manuscript.

\section{REFERENCES}

Abu-El Samen, F. M., Secor, G. A. \& Gudmestad, N. C. (2003) Genetic variation among asexual progeny of Phytophthora infestans detected with RAPD and AFLP markers. Plant Pathology 52: 314-325.

Agapow, P. M. \& Burt, A. (2001) Indices of multilocus linkage disequilibrium. Molecular Ecology Notes 1: 101-102.

Anagnostakis, S. L. (1988) Cryphonectria parasitica cause of chestnut blight. Advances in Plant Pathology 6: 123-136.

Bonants, P. J. M., Hagenaar-de Weerdt, M., van Gent-Pelzer, M. P. E., Lacourt, I., Cooke, D. E. L. \& Duncan, J. M. (1997) Detection and identification of Phytophthora fragariae Hickman by the polymerase chain reaction. European Journal of Plant Pathology 103: 345-355.

Brasier, C. M. (1995) Episodic selection as a force in fungal microevolution, with special reference to clonal speciation and hybrid introgression. Canadian Journal of Botany 73 (Suppl. 1): S1213-S1221.

Brasier, C. M., Rose, J., Kirk, S. A. \& Webber, J. F. (2002) Pathogenicity of Phytophthora ramorum isolates from North America and Europe to bark of European Fagaceae, American Quercus rubra and other forest trees. Paper abstract. Sudden Oak Death Science Symposium, 15-18 December 2002 in Monterey, CA. http://danr. ucop.edu/ihrmp/sodsymp/paper/paper09.html.

Brasier, C. M. (2003) Sudden oak death exhibits transatlantic differences. Mycological Research 107: 258-259.

Casgrain, P. \& Legendre, P. (1999) The R package for multivariate and spatial analysis. University of Montreal, Montreal.

Cooke, D. E. L., Drenth, A., Duncan, J. M., Wagels, G. \& Brasier, C. M. (2000) A molecular phylogeny of Phytophthora and related oomycetes. Fungal Genetics and Biology 30: 17-32.

Davidson, J. M., Werres, S., Garbelotto, M., Hansen, E. M. \& Rizzo, D. M. (2003) Sudden oak death and associated diseases caused by Phytophthora ramorum. Online. Plant Health Progress doi: 10.1094/PHP-2003-0707-01-DG.

Dobrowolski, M. P., Tommerup, I. C., Chearer, B. L. \& O'Brien, P. A. (2003) Three clonal lineages of Phytophthora cinnamomi in Australia revealed by microsatellites. Phytopathology 93: 695-704.

Dudzinski, M. J., Old, K. M. \& Gibbs, R. J. (1993) Pathogenic variability in Australian isolates of Phytophthora cinnamomi. Australian Journal of Botany 41: 721-732.

Felsenstein, J. (1985) Confidence limits on phylogenies: an approach using the bootstrap. Evolution 39: 783-791.

Garbelotto, M., Davidson, J. M., Ivors, K., Maloney, P. E., Hüberli, D., Koike, S. T. \& Rizzo, D. M. (2003) Non-oak native plants are main hosts for sudden oak death pathogen in California. California Agriculture 57: 18-23.

Goodwin, S. B., Spielman, L. J., Matuszak, J. M., Bergeron, S. N. \& Fry, W. E. (1992) Clonal diversity and genetic recombination of Phytophthora infestans populations in northern and central Mexico. Phytopathology 82: 955-961.

Goodwin, S. B., Cohen, B. A. \& Fry, W. E. (1994) Panglobal distribution of a single clonal lineage of the Irish potato famine fungus. Proceedings of the National Academy of Sciences, USA 91: 11591-11595.

Hansen, E. M., Goheen, D. J., Jules, E. S. \& Ullian, B. (2000) Managing Port-Orford-Cedar and the introduced pathogen Phytophthora lateralis. Plant Disease 84: 4-10.

Hansen, E. M., Reeser, P. W., Sutton, W., Winton, L. \& Osterbauer, N. (2003) First report of A1 mating type of Phytophthora ramorum in North America. Plant Disease 87: 1267.

Hoegger, P. J., Rigling, D., Holdenrieder, O. \& Heiniger, U. (2000) Genetic structure of newly established populations of Cryphonectria parasitica. Mycological Research 104: 1108-1116.
Jaccard, P. (1908) Nouvelles recherches sur la distribution florale. Bulletin de la Société Vaudoise des Sciences Naturelles $\mathbf{4 4}$ 223-270.

Jung, T., Nechwatal, J., Cooke, D. E. L., Hartmann, G., Blaschke, M., Oswald, W. F., Duncan, J. M. \& Delatour, C. (2003) Phytophthora pseudosyringae sp. nov., a new species causing root and collar rot of deciduous tree species in Europe. Mycological Research 107: 772-789.

Kumar, S., Tamura, K., Jakobsen, I. B. \& Nei, M. (2001) Mega2: molecular evolutionary genetics analysis software. Bioinformatics 17: 1244-1245.

Lamour, K. H. \& Hausbeck, M. K. (2001) Investigating the spatiotemporal genetic structure of Phytophthora capsici in Michigan. Phytopathology 91 : 973-980.

Linde, C., Drenth, A., Kemp, G. H. J., Wingfield, M. J. \& von Broembsen, S. L. (1997) Population structure of Phytophthora cinnamomi in South Africa. Phytopathology 87: 822-827.

Little, E. L. jr. (1979) Checklist of United States Trees (Native and Naturalized). [Agriculture Handbook no. 541.] USDA, Washington, DC.

Martin, F. N. (2000) Phylogenetic relationships among some Pythium species inferred from sequence analysis of the mitochondrially encoded cytochrome oxidase II gene. Mycologia 92: 711-727.

Martin, F. N. \& Tooley, P. W. (2003) Phylogenetic relationships among Phytophthora species inferred from sequence analysis of mitochondrially encoded cytochrome oxidase I and II genes. Mycologia 95: 269-284.

Maynard Smith, J., Smith, N. H., O’Rourke, M. \& Spratt, B. G. (1993) How clonal are bacteria? Proceedings of the National Academy of Sciences, USA 90: 4384-4388.

Moralejo, E. \& Werres, S. (2002) First report of Phytophthora ramorum on Rhododendron sp. in Spain. Plant Disease 86: 1052.

Morehouse, E. A., James, T. Y., Ganley, A. R. D., Vilgalys, R., Berger, L., Murphy, P. J. \& Longcore, J. E. (2003) Multilocus sequence typing suggests the chytrid pathogen of amphibian is a recently emerged clone. Molecular Ecology 12: 395-403.

Péros, J.-P., Berger, G. \& Lahogue, F. (1997) Variation in pathogenicity and genetic structure in the Eutypa lata population of a single vineyard. Phytopathology 87: 799-806.

Pogoda, F. \& Werres, S. (2002) Pathogenicity of European and American Phytophthora ramorum isolates to Rhododendron. Poster abstract. Sudden Oak Death Science Symposium, 15-18 December 2002 in Monterey, CA. http://danr.ucop.edu/ihrmp/sodsymp/ poster/poster26.html.

Rambaut, A. (1996) Se-Al: Sequence Alignment Editor. http://evolve. zoo.ox.ac.uk/software.html.

Redecker, D., Szaro, T. M., Bowman, R. J. \& Bruns, T. D. (2001) Small genets of Lactarius xanthogalactus, Russula cremoricolor and Amanita francheti in late-stage ectomycorrhizal successions. Molecular Ecology 10: 1025-1034.

Rizzo, D. M., Garbelotto, M., Davidson, J. M., Slaughter, G. W. \& Koike, S. (2002) Phytophthora ramorum as the cause of extensive mortality of Quercus spp. and Lithocarpus densiflorus in California. Plant Disease 86: 205-214.

Rizzo, D. M. \& Garbelotto, M. (2003) Sudden oak death: endangering California and Oregon forest ecosystems. Frontiers in Ecology and the Environment 1: 197-204.

Sansome, E. (1980) Reciprocal translocation heterozygosity in heterothallic species of Phytophthora and its significance. Transactions of the British Mycological Society 74: 175-185.

Swofford, D. L. (2002) PAUP* : phylogenetic analysis using parsimony (* and other methods). Version 4. Sinauer Associates, Sunderland, MA.

Tooley, P. W., Fry, W. E. \& Villareal Gonzalez, M. J. (1985) Isozyme characterization of sexual and asexual Phytophthora infestans populations. Journal of Heredity 76: 431-435.

Vos, P., Hogers, R., Bleeker, M., Reijans, M., van de Lee, T., Hornes, M., Frijters, A., Pot, J., Peleman, J., Kuiper, M. \& Zabeau, M. 
(1995) AFLP: a new technique for DNA fingerprinting. Nucleic Acids Research 23: 4407-4414.

Werres, S., Marwitz, R., Man in't Veld, W. A., De Cock, A. W. A. M., Bonants, P. J. M., de Weerdt, M., Themann, K., Ilieva, E. \& Baayen, R. P. (2001) Phytophthora ramorum sp. nov., a new pathogen on Rhododendron and Viburnum. Mycological Research 105: 1155-1165.

Werres, S. \& de Merlier, D. (2003) First detection of Phytophthora ramorum mating type A2 in Europe. Plant Disease 87: 1266.

Werres, S. \& Zielke, B. (2003) First studies on the pairing of Phytophthora ramorum. Journal of Plant Disease and Protection 110: $129-130$
White, T. J., Bruns, T., Lee, S. \& Taylor, J. (1990) Amplification and direct sequencing of fungal ribosomal RNA genes for phylogenetics. In PCR Protocols: a guide to methods and applications (M. A. Innis, D. H. Gelfand, J. J. Sninsky \& T. J. White, eds): 315-322. Academic Press, San Diego.

Zentmyer, G. A. (1988) Origin and distribution of four species of Phytophthora. Transactions of the British Mycological Society 91: 367-378.

Corresponding Editor: D. L. Hawksworth 